\title{
The First $\mathrm{I}_{2}$-Promoted Efficient Aminoacetylation of Activated Aziridines in Ionic Liquid
}

\author{
Vijai K. Rai, ${ }^{* a, b}$ Nihar Sharma, ${ }^{\text {b Anil Kumar }}{ }^{\mathrm{b}}$ \\ a Department of Applied Chemistry, Institute of Technology, Guru Ghasidas Vishwavidyalaya, Bilaspur, Chhattisgarh 495 009, India \\ b School of Biology and Chemistry, Shri Mata Vaishno Devi University, Katra, Jammu \& Kashmir 182 320, India \\ Fax +91(7752)260148; E-mail: vijaikrai@hotmail.com
}

Received: 27.10.2012; Accepted after revision: 29.10.2012

\begin{abstract}
A novel and efficient aminoacetylation of aziridines is reported. Herein, 2-phenyl-1,3-oxazolan-5-one with tosylaziridines affords 3-(N-substituted)aminopyrrolidin-2-ones via regioselective terminal aziridine opening-aminoacetylative cyclization cascades. The reaction is performed using $[\mathrm{bmim}] \mathrm{OH} / \mathrm{molecular}$ iodine as a new catalyst system where ionic liquid [bmim] $\mathrm{OH}$ also works as reaction media and proceeds via an isolable intermediate. After isolation of the product, the ionic liquid, [bmim $] \mathrm{OH}$ can be easily recycled for further use without any loss of efficiency. No byproduct formation, operational simplicity, ambient temperature, high yield, and excellent diastereoselectivity are salient features of the present synthetic protocol.
\end{abstract}

Key words: pyrrolidine-2-ones, ionic liquid, aziridines, diastereoselectivity, molecular iodine

Aziridines are an elite class of compounds present in various natural products and have been useful intermediates as well as building blocks in organic synthesis. ${ }^{1}$ In terms of synthetic transformations, the utility of aziridines derives from their selective ring-opening reactions with various nucleophiles, which often form the basis for more complex target syntheses, especially $\mathrm{N}$-containing compounds. ${ }^{2,3} \gamma$-Butyrolactams (pyrrolidin-2-ones) are a class of versatile core structures present in various natural products such as isocynamatrine $e^{4 a, b}$ and clausenamide $e^{4 c-f}$ and are also important intermediates in the synthesis of a variety of nitrogenated heterocycles with interesting biological activities (Figure 1). ${ }^{4-8}$

Due to their versatile applications in organic and medicinal chemistry, the development of new synthetic routes for the preparation of pyrrolidin-2-ones is an important endeavor and has been well documented in the literature. ${ }^{10-21}$ However, most of the reactions suffer from one or more disadvantages, such as expensive reagents, long reaction times, low yields, tedious workup, and, most importantly, none of these methods cater a direct process for the synthesis of 3-(N-substituted)aminopyrrolidin-2-ones and tend to be lengthy and cumbersome if the lactam contains any sort of substitution. Recently, Ghorai et al. have reported the synthesis of pyrrolidin-2-one via a nucleophilic ring opening with a methylene group ${ }^{22 a}$ in addition to other literature reports on the synthesis of 4-(N-substi-

SYNLETT 2013, 24, 0097-0101

Advanced online publication: 04.12.2012

DOI: 10.1055/s-0032-1317675; Art ID: ST-2012-B0924-L

(C) Georg Thieme Verlag Stuttgart · New York tuted)aminopyrroildin-2-ones. ${ }^{22 b, c}$ Very recently, we have reported the synthesis of 3-mercapto-pyrrolidin-2-one starting via ring opening of aziridines with masked mercaptoacid. ${ }^{22 \mathrm{~d}}$ To date, there is no report on the direct synthesis of 3-aminopyrrolidin-2-ones.
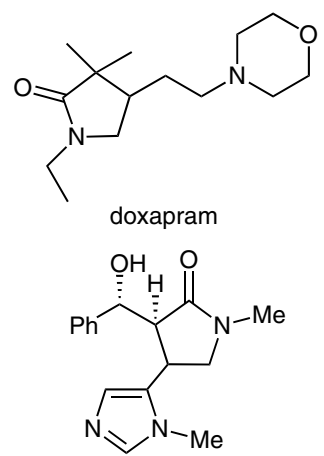

$( \pm)$-isocynometrine
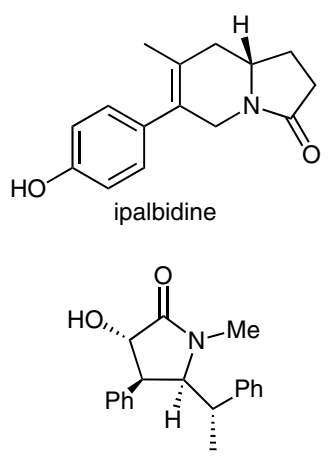

(-)-clausenamide
Figure 1 Pyrrolidin-2-one ring-containing natural products and pharmaceutical molecules

Ionic liquids (IL) have attracted much attention as environmentally friendly reaction media, ${ }^{23-25}$ catalysts, ${ }^{26-28}$ and reagents ${ }^{29,30}$ and are also easy to recycle. ${ }^{29,30}$ Moreover, the synthesis of amides is important in many areas of chemistry, including peptide, polymer, and complex molecule synthesis. ${ }^{31}$ Inspired by these valid points and keeping the synthetic and pharmacological importance of the amide group in mind we turned our attention to utilize masked amino acids as substrates viz. 2-phenyl-1,3-oxazolan-5-one, which can introduce an amide group at the $\alpha$ position into $\gamma$-lactam, which is the target molecule in the present investigation.

In this Letter, we report a new molecular-iodine-catalyzed one-pot atom efficient method for the preparation of 3-(Nsubstituted)aminopyrrolidin-2-ones 3 in a single step using [bmim] $\mathrm{OH}$ as a green reaction promoter. This one-pot synthetic protocol is highly atom efficient as there is no byproduct formation and involves novel utilization of the masked amino acid 2-phenyl-1,3-oxazolan-5-one (1) with terminal aziridines 2 affording 3-(N-substituted)aminopyrrolidin-2-ones 3 in high yield and excellent diastereoselectivity, in favor of the cis isomer (Scheme 1). Furthermore, the present synthesis of 3-(N-substituted)amino functionalized $\gamma$-lactam 3 is an outcome of our 
quest for developing new synthetic routes employing green chemistry protocols. ${ }^{32}$

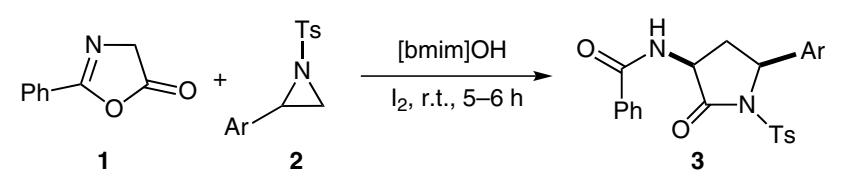

Scheme 1 One-pot aminoacetylation of aziridines $\mathbf{2}$ in ionic liquid $[\mathrm{bmim}] \mathrm{OH}$

In a preliminary experimentation, a controlled reaction was carried out using 2-phenyl-1,3-oxazolan-5-one (1) and aziridine $2 \mathrm{a}(\mathrm{Ar}=\mathrm{Ph})$ in $[\mathrm{bmim}] \mathrm{OH}$ but the reaction did not afford the desired $\gamma$-lactam 3a (Table 1, entry 1) even after 48 hours, rather conversion of tosylaziridines 2a into the corresponding amine 4a was observed (Scheme 2). Then, we turned our attention to use molecular iodine as catalyst in conjunction with different roomtemperature ionic liquid (RTIL). For this purpose, 2-phenyl-1,3-oxazolan-5-one (1) and aziridine $\mathbf{2 a}(\mathrm{R}=\mathrm{Ph})$ were chosen as model substrates for the synthesis of representative compound 3a (Table 1) wherein molecular iodine evidenced its catalytic efficacy in conjunction with RTIL, affording 3a in excellent yield (Table 1, entry 1). A variety of RTIL were screened for the present reaction and amongst $[\mathrm{bmim}] \mathrm{BF}_{4}, \quad[\mathrm{bmim}] \mathrm{OH}, \quad[\mathrm{bmim}] \mathrm{PF}_{6}$, and [bmim] Br, [bmim] $\mathrm{OH}$ was found to be the most effective RTIL for the conversion of the tosyl aziridine $2 \mathbf{a}$ to the corresponding $\gamma$-lactam 3a (Table 1, entries 2-4).

In order to elucidate the role of other solvents in lieu of RTIL as reaction medium, various solvents were used under the present reaction conditions. The results validate our premise that the reaction would not only be faster but also result in higher yield using RTIL as compared to other conventional solvents (Table 1, entries 2, 5-9). Interestingly, yield of the target compound $\mathbf{3 a}$ is poor using polar aprotic solvents (Table 1, entries 8 and 9). Thus, RTIL [bmim] OH stands out as the choice, with its fast conversion and quantitative yield in conjunction with molecular iodine, as an inexpensive and versatile catalyst in the present envisaged synthetic protocol. The optimum catalyst loading for molecular iodine was found to be $10 \mathrm{~mol} \%$. When the amount of catalyst decreased from $10 \mathrm{~mol} \%$ to $5 \mathrm{~mol} \%$ relative to the substrates, the yield of product $\mathbf{3 a}$ was reduced (Table 2, entries 2 and 10). However, the use of $15 \mathrm{~mol} \%$ of the catalyst showed the same yield, and the same time was required (Table 1, entries 2 and 11). It was noted that a higher reaction temperature (up to $60^{\circ} \mathrm{C}$ ) instead of room temperature had no appreciable effect on the yield.

Next, in order to investigate the substrate scope for the general validity of the present investigation, a variety of tosyl aziridines 2 were used under the optimized reaction conditions, and different 3-(N-substituted)aminopyrrolidin-2-ones 3 were synthesized. The yields were consistently good (Table 2), and the highest yield was $96 \%$ (Table 2, entry 3 ). Thus, the present optimized synthesis is accomplished by stirring a mixture of 2-phenyl-1,3oxazolan-5-one (1), aziridine 2 , and molecular iodine in $[\mathrm{bmim}] \mathrm{OH}$ at room temperature for 5-6 hours. ${ }^{33}$

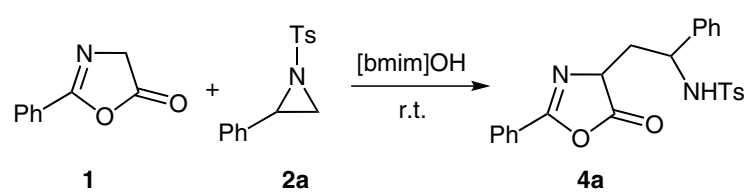

Scheme 2 Reaction of masked amino acid $\mathbf{1}$ and aziridines $\mathbf{2}$ in [bmim $] \mathrm{OH}$

Table 1 Optimization of Reaction Conditions for the Formation of $3 \mathrm{a}^{\mathrm{a}}$

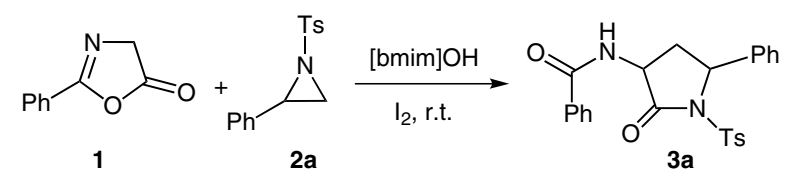

\begin{tabular}{lllll}
\hline Entry & RTIL/solvent & $\mathrm{I}_{2}(\mathrm{~mol} \%)$ & Time $\left.^{(h)}\right)^{\mathrm{b}}$ & Yield (\%) $^{\mathrm{c}}$ \\
\hline 1 & {$[\mathrm{bmim}] \mathrm{OH}$} & - & 48 & - \\
2 & {$[\mathrm{bmim}] \mathrm{OH}$} & 10 & 5 & 94 \\
3 & {$[\mathrm{bmim}] \mathrm{PF}_{6}$} & 10 & 10 & 86 \\
4 & {$[\mathrm{bmim}] \mathrm{Br}$} & 10 & 10 & 88 \\
5 & $1,4-\mathrm{dioxane}$ & 10 & 17 & 74 \\
6 & $\mathrm{MeCN}_{7}$ & 10 & 15 & 78 \\
8 & $\mathrm{CH}_{2} \mathrm{Cl}$ & 10 & 18 & 75 \\
9 & DMF & 10 & 16 & 41 \\
10 & DMSO & 10 & 16 & 46 \\
11 & {$[\mathrm{bmim}] \mathrm{OH}$} & 5 & 5 & 88 \\
\hline
\end{tabular}

${ }^{\text {a }}$ Reaction conditions: 1 ( $\left.2 \mathrm{mmol}\right), \mathbf{2 a}(2 \mathrm{mmol}), \mathrm{I}_{2}(0.2 \mathrm{mmol})$, [bmim] OH $(5 \mathrm{~mL})$.

${ }^{\mathrm{b}}$ Stirring time at r.t.

${ }^{c}$ Yield of isolated and purified product 3a.

Isolation and purification by recrystallization afforded the target compound 3 in $85-96 \%$ yield with $96-98 \%$ diastereoselectivity (Table 2) in favor of the cis isomer. Product 3 was extracted with EtOAc leaving the $[\mathrm{bmim}] \mathrm{OH}$ behind, which can be recycled easily for further use without loss of efficiency (Table 3). The diastereomeric ratios in the crude isolates were checked by ${ }^{1} \mathrm{H}$ NMR spectroscopy to note any alteration of these ratios during subsequent purification. The crude isolates of $\mathbf{3}$ were found to be a diastereomeric mixture containing $96-98 \%$ of the cis isomer.

On the basis of ${ }^{1} \mathrm{H}$ NMR spectroscopy and the literature precedent, ${ }^{34}$ the cis stereochemistry was conclusively assigned to 3 , as their coupling constants $\left(J_{5 \mathrm{H}, 4 \mathrm{Ha}}=7.0-7.6\right.$ $\mathrm{Hz}, J_{5 \mathrm{H}, 4 \mathrm{Hb}}=6.3-6.7 \mathrm{~Hz}$ ) was lower than that for the minor trans isomer $\left(J_{5 \mathrm{H}, 4 \mathrm{Ha}}=10.5-10.8 \mathrm{~Hz}, J_{5 \mathrm{H}, 4 \mathrm{Hb}}=11.5-11.9\right.$ $\mathrm{Hz}$ ). Furthermore, the assigned cis stereochemistry of lac- 
Table 2 One-Pot Synthesis of 3-(N-Substituted)aminopyrrolidin-2ones 3

\begin{tabular}{|c|c|c|c|c|c|c|}
\hline Entry & $\begin{array}{l}\text { Aziridine } \\
\mathbf{2}\end{array}$ & $\mathrm{Ar}$ & $\begin{array}{l}\text { Time } \\
(\mathrm{h})^{\mathrm{a}, \mathrm{b}}\end{array}$ & $\begin{array}{l}\text { Product } \\
\mathbf{3}\end{array}$ & $\begin{array}{l}\text { Yield } \\
(\%)^{\mathrm{c}, \mathrm{d}}\end{array}$ & $\begin{array}{l}\text { cis/ } \\
\text { trans }^{\mathrm{e}}\end{array}$ \\
\hline 1 & $2 a$ & $\mathrm{Ph}$ & 5 & $3 \mathbf{a}$ & 94 & $96: 4$ \\
\hline 2 & $2 \mathbf{b}$ & $4-\mathrm{MeOC}_{6} \mathrm{H}_{4}$ & 5 & $3 b$ & 89 & $96: 4$ \\
\hline 3 & $2 \mathrm{c}$ & $4-\mathrm{O}_{2} \mathrm{NC}_{6} \mathrm{H}_{4}$ & 5 & $3 c$ & 96 & $98: 2$ \\
\hline 4 & $2 d$ & 4- $\mathrm{BrC}_{6} \mathrm{H}_{4}$ & 5 & $3 d$ & 93 & $96: 4$ \\
\hline 5 & $2 \mathrm{e}$ & $4-\mathrm{ClC}_{6} \mathrm{H}_{4}$ & 5 & $3 e$ & 92 & $98: 2$ \\
\hline 6 & $2 f$ & $3-\mathrm{ClC}_{6} \mathrm{H}_{4}$ & 5 & $3 f$ & 95 & $98: 2$ \\
\hline 7 & $2 \mathrm{~g}$ & $4-\mathrm{MeC}_{6} \mathrm{H}_{4}$ & 6 & $3 g$ & 88 & $97: 3$ \\
\hline 8 & $2 \mathrm{~h}$ & 4- $\mathrm{AcC}_{6} \mathrm{H}_{4}$ & 6 & $3 \mathbf{h}$ & 91 & $97: 3$ \\
\hline 9 & $2 \mathbf{i}$ & 4- $\mathrm{FC}_{6} \mathrm{H}_{4}$ & 5 & $3 \mathbf{i}$ & 85 & $96: 4$ \\
\hline 10 & $2 \mathrm{j}$ & $3-\mathrm{MeC}_{6} \mathrm{H}_{4}$ & 6 & $3 \mathbf{j}$ & 91 & $97: 3$ \\
\hline 11 & $2 \mathbf{k}$ & $3-\mathrm{BrC}_{6} \mathrm{H}_{4}$ & 5 & $3 \mathbf{k}$ & 94 & $98: 2$ \\
\hline 12 & 21 & 1-naphthyl & 5 & 31 & 89 & $98: 2$ \\
\hline
\end{tabular}

${ }^{a}$ Reaction conditions: $\mathbf{1}$ ( $\left.2 \mathrm{mmol}\right), \mathbf{2 a}(2 \mathrm{mmol}), \mathrm{I}_{2}(0.2 \mathrm{mmol})$, [bmim] OH $(5 \mathrm{~mL})$.

${ }^{\mathrm{b}}$ Stirring time at r.t.

${ }^{c}$ Yield of isolated and purified product.

${ }^{\mathrm{d}}$ All compounds gave $\mathrm{C}, \mathrm{H}$, and $\mathrm{N}$ analyses $\pm 0.39 \%$ and satisfactory spectral (IR, ${ }^{1} \mathrm{H}$ NMR, ${ }^{13} \mathrm{C}$ NMR] and MS (EI) data.

${ }^{\mathrm{e}}$ As determined by ${ }^{1} \mathrm{H}$ NMR spectroscopy of the crude products.

tams 3 was also established by NOE observations (Figure 2). For example, $7.8 \%$ NOE was observed by between 5$\mathrm{H}$ and $4-\mathrm{H}_{\mathrm{a}} ; 8.1 \%$ between $3-\mathrm{H}$ and $4-\mathrm{H}_{\mathrm{a}}$ of product 3a. This indicates that $3-\mathrm{H}, 4-\mathrm{H}_{\mathrm{a}}$, and $5-\mathrm{H}$ are located on the same face of the molecule, that is, cis to one another.

The formation of 3-(N-substituted)aminopyrrolidin-2ones 3 can be rationalized by nucleophilic attack of the methylene carbon $(\mathrm{C}-4)$ of the masked amino acid $\mathbf{1}$ to the less substituted carbon of tosyl aziridine 2 regioselectively, followed by protonation of aziridine nitrogen leading to the intermediate $\mathbf{4}$ (Scheme 3 ). The adduct $\mathbf{4}$ undergoes intramolecular nucleophilic attack of the nitrogen atom of the NHTs group at the carbonyl carbon (C-5) of the 1,3oxazolan-5-one moiety to yield the target compounds 3 (Scheme 3). This conclusion is based on the observation that the representative intermediate compounds $4 \mathrm{a}(\mathrm{Ar}=$ $\mathrm{Ph}), 4 \mathbf{e}\left(\mathrm{Ar}=4-\mathrm{ClC}_{6} \mathrm{H}_{4}\right)$, and $\mathbf{4 i}\left(\mathrm{Ar}=4-\mathrm{FC}_{6} \mathrm{H}_{4}\right)$ could be isolated in $41-49 \%$ yield, these could be converted into the corresponding lactams $\mathbf{3 a}, \mathbf{3 e}$, and $\mathbf{3 i}$ in quantitative yields. ${ }^{35}$

Presumably, in the ring-transformation step, iodine plays a key role in the reaction by polarizing the carbonyl group of the substrate 1, thereby enhancing the electrophilicity of the carbonyl carbon, which facilitates the nucleophilic attack of the NHTs of aziridine 2. Usually, the electronic factor favors the aziridine ring opening by a nucleophilic attack at the benzylic carbon. However, when the steric factor predominates over the electronic factor, the nucleophile prefers to attack at the terminal carbon rather than the benzylic carbon. ${ }^{36}$ Here, presumably due to bulky nature of the attacking nucleophile, the steric factor predominates over the electronic effect to afford products 3 .

Table 3 Recyclability of [bmim] OH in the Synthesis of 3a

\begin{tabular}{llllll}
\hline Run & 1 & 2 & 3 & 4 & 5 \\
\hline Yield (\%) & 96 & 96 & 95 & 95 & 92 \\
\hline
\end{tabular}

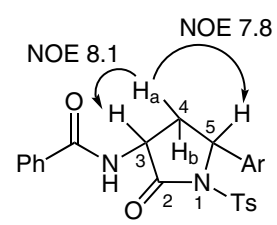

Figure 2 NOE observations of pyrrolidin-2-ones 3

In conclusion, we have documented an original and practical regio- and diastereoselective route to synthetically and pharmaceutically important 3-(N-substituted)aminopyrrolidin-2-ones via nucleophilic aziridine ring opening with a novel substrate viz. 2-phenyl-1,3-oxazolan-5-one.

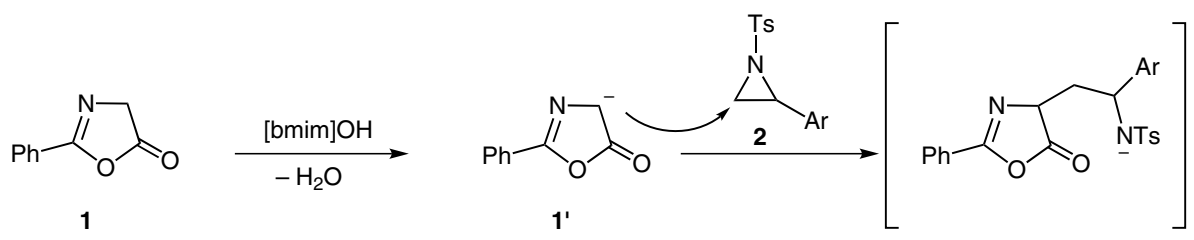

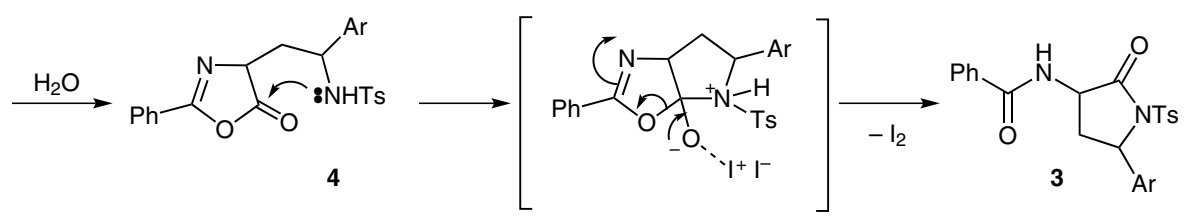

Scheme 3 Plausible mechanism for the formation of 3-(N-substituted)aminopyrrolidin-2-ones 3 
The efficacy of the reaction lies in its high yield, no byproduct formation, ambient temperature, and recyclability of the ionoc liquid [bmim] OH. Thus, this simple methodology would be a practical alternative to the existing procedures for the production of this kind of fine chemicals to cater to the need of academia as well as of industry.

\section{Acknowledgment}

We sincerely thank the CSIR, New Delhi (01(2441)/10/EMR-II) and UGC, New Delhi [F. No. 39-764/2010 (SR)] for financial support. We are also thankful to IIIM Jammu and SAIF, Punjab University, Chandigarh, for providing microanalyses and spectra.

\section{References and Notes}

(1) (a) Gabriel, S. Ber. Dtsch. Chem. Ges. 1888, 21, 1049.

(b) Tanner, D. Angew. Chem., Int. Ed. Engl. 1994, 33, 599.

(c) Aziridines and Epoxides in Organic Synthesis; Yudin, A. K., Ed.; Wiley-VCH: Weinheim, 2006. (d) Muller, P.; Fruit, C. Chem. Rev. 2003, 103, 2905. (e) Hu, X. E. Tetrahedron 2004, 60, 2701.

(2) (a) Hu, X. E. Tetrahedron 2004, 60, 2701. (b) Sweeney, J. B. Chem. Soc. Rev. 2002, 31, 247. (c) Grahm, M. A.; Wadsworth, A. H.; Thornton-Pett, M.; Rayner, C. M. Chem. Commun. 2001, 966. (d) Watson, I. D. G.; Yu, L.; Yudin, A. K. Acc. Chem. Res. 2006, 39, 194. (e) Watson, I. D. G.; Yudin, A. K. J. Org. Chem. 2003, 68, 5160.

(3) (a) Wang, Z.; Cui, Y.-T.; Xu, Z.-B.; Qu, J. J. Org. Chem. 2008, 73, 2270. (b) Minakata, S.; Hotta, T.; Oderaotoshi, Y.; Komatsu, M. J. Org. Chem. 2006, 71, 7471. (c) Lu, P. Tetrahedron 2010, 66, 2549. (d) Garima, V. P. S.; Yadav, L. D. S. Green Chem. 2010, 12, 1460. (e) Minakata, S.; Kano, D.; Oderaotoshi, Y.; Komatsu, M. Angew. Chem. Int. Ed. 2004, 43, 79. (f) Vicario, J. L.; Badía, D.; Carrillo, L. J. Org. Chem. 2001, 66, 5801.

(4) (a) Khuong-Huu, F.; Monseur, X.; Ratle, G.; Lukacs, G.; Goutarel, R. Tetrahedron Lett. 1973, 14, 1757. (b) Chiaroni, A.; Riche, C.; Tchissambou, L.; Khuong-Huu, F. J. Chem. Res., Synop. 1981, 182. (c) Yang, M.-H.; Cao, Y.-H.; Li, W.X. Yaохие Хиebao 1987, 22, 33. (d) Xu, L.; Liu, S.-L.; Zhang, J.-T. Chirality 2005, 17, 239. (e) Yu, L.; Liu, G. Zhongguo Yaoxue Zazhi 2000, 35, 446. (f) Liu, Y.; Shi, C. Z.; Zhang, J. T. Yaoxue Xuebao 1991, 26, 166.

(5) (a) Yang, D.; Lian, G.-Y.; Yang, H.-F.; Yu, J.-D.; Zhang, D.W.; Gao, X. J. Org. Chem. 2009, 74, 8610. (b) Duan, X. J.; Li, X. M.; Wang, B. G. J. Nat. Prod. 2007, 70, 1210. (c) Donohue, S. R.; Krushinski, J. H.; Pike, V. W.; Chernet, E.; Phebus, L.; Chesterfield, A. K.; Felder, C. C.; Halldin, C.; Schaus, J. M. J. Med. Chem. 2008, 51, 5833. (d) Kulig, K.; Sapa, J.; Nowaczyk, A.; Filipek, B.; Malawska, B. Eur. J. Med. Chem. 2009, 3994. (e) Chang, T.; Hattori, M.; Sheu, C. WO 2009094807-A1, 2009. (f) Ngo, V. X.; Old, D. W. WO 2009055289-A2, 2009. (g) Hook, D.; Ruch, T.; Riss, B.; Wietfeld, B.; Sedelmeier, G.; Napp, M.; Baenziger, M.; Hawker, S.; Ciszewski, L.; Waykole, L. M. WO 2008083967-A2, 2008. (h) Bush, J. K.; Hansen, M. M.; Li, R.; Mabry, T. E.; Snyder, N. J.; Wallace, O. B.; Xu, Y. WO 2007127688-A2, 2007. (i) Kenda, B.; Quesnel, Y.; Ates, A.; Michel, P.; Turet, L.; Mercier, J. WO 2006128692-A2, 2006.

(6) (a) Kralj, D.; Novak, A.; Dahmann, G.; Grošelj, U.; Meden, A.; Svete, J. J. Comb. Chem. 2008, 10, 664. (b) Bagnoli, L.; Cacchi, S.; Fabrizi, G.; Goggiamani, A.; Scarponi, C.; Tiecco, M. J. Org. Chem. 2010, 75, 2134.
(7) Parsons, A. F. Tetrahedron 1996, 52, 4149; and references cited therein.

(8) (a) Biggs-Houck, J. E.; Davis, R. L.; Wei, J.; Mercado, B. Q.; Olmstead, M. M.; Tantillo, D. J.; Shaw, J. T. J. Org. Chem. 2012, 77, 160. (b) Jakubec, P.; Cockfield, D. M.; Dixon, D. J. J. Am. Chem. Soc. 2009, 131, 16632.

(9) Elford, T. G.; Lesanko, A. U.-L.; Pascale, G. D.; Wright, G. D.; Hall, D. G. J. Comb. Chem. 2009, 11, 155.

(10) Alcaide, B.; Almendros, P.; Cabrero, G.; Ruiz, M. P. Org. Lett. 2005, 7, 3981

(11) Yang, L.; Zheng, Q.-Y.; Wang, D.-X.; Huang, Z.-T.; Wang, M.-X. Org. Lett. 2008, 10, 2461.

(12) Pelletier, S. M.-C.; Ray, P. C.; Dixon, D. J. Org. Lett. 2009, $11,4512$.

(13) Mapes, C. M.; Mani, N. S. Org. Process Res. Dev. 2007, 11, 482.

(14) Sell, M. S.; Klein, W. R.; Rieke, R. D. J. Org. Chem. 1995, 60, 1077.

(15) Soloshonok, V. A.; Cai, C.; Hruby, V. J. J. Org. Chem. 2000, 65,6688

(16) Garcia, A. L. L.; Carpes, M. J. S.; de Oca, A. C. B. M.; dos Santos, M. A. G.; Santana, C. C.; Correia, C. R. D. J. Org. Chem. 2005, 70, 1050.

(17) Krawczyk, H.; Albrecht, Ł.; Wojciechowski, J.; Wolf, W. M.; Krajewska, U.; Różalski, M. Tetrahedron 2008, 64, 6307.

(18) Xie, C.; Han, D.; Hu, Y.; Liu, J.; Xie, T. Tetrahedron Lett. 2010, 51, 5238.

(19) Basavaiah, D.; Rao, J. S. Tetrahedron Lett. 2004, 45, 1621.

(20) Leśniak, S.; Pasternak, B. Tetrahedron Lett. 2005, 46, 3093.

(21) Leśniak, S.; Nazarski, R. B.; Pasternak, B. Tetrahedron 2009, 65, 6364.

(22) (a) Ghorai, M. K.; Tiwari, D. P. J. Org. Chem. 2010, 75, 6173. (b) Bisol, T. B.; Bortoluzzi, A. J.; Sá, M. M. J. Org. Chem. 2011, 948. (c) Hoang, C. T.; Bouillére, F.;

Johannesen, S.; Zulauf, A.; Panel, C.; Pouilhés, A.; Gori, D.; Alezra, V.; Kouklovsky, C. J. Org. Chem. 2009, 74, 4177. (d) Rai, V. K.; Rai, P. K.; Bajaj, S.; Kumar, A. Green Chem. 2011, 13, 1217.

(23) Chowdhury, S.; Mohan, R. S.; Scott, J. L. Tetrahedron 2007, 63, 2363.

(24) Bao, W.; Wang, Z. Green Chem. 2006, 8, 1028.

(25) Zhao, D.; Wu, M.; Kou, Y.; Min, E. Catal. Today 2002, 74, 157.

(26) Dupont, J.; de Souza, R. F.; Suarez, P. A. Z. Chem. Rev. 2002, 102, 3667

(27) Qiao, K.; Yakoyama, C. Chem. Lett. 2004, 33, 472.

(28) Sun, W.; Xia, C.-G.; Wang, H.-W. Tetrahedron Lett. 2003, 44, 2409.

(29) Kamal, A.; Chouhan, G. Tetrahedron Lett. 2005, 46, 1489.

(30) Earle, M. J.; Ktdare, S. P.; Seddon, K. R. Org. Lett. 2004, 6, 707.

(31) (a) Benz, G. In Comprehensive Organic Synthesis; Vol. 6; Trost, B. M.; Fleming, I., Eds.; Chap. 2.3; Pergamon Press: Oxford, 1991. (b) Albericio, F.; Chinchilla, R.; Dodsworth, D. J.; Najera, C. Org. Prep. Proced. Int. 2001, 33, 203.

(32) (a) Rai, V. K.; Tiku, P.; Kumar, A. Synth. Commun. 2012, 42, 1489. (b) Rai, V. K.; Singh, S.; Singh, P.; Yadav, L. D. S. Synthesis 2010, 4051. (c) Yadav, L. D. S.; Singh, S.; Rai, V. K. Green Chem. 2009, 11, 878. (d) Yadav, L. D. S.; Rai, V. K. Tetrahedron Lett. 2006, 47, 395.

(33) General Procedure for the Synthesis of $\gamma$-Lactams 3 A mixture of 2-phenyl-1,3-oxazol-5-one (1, $2.0 \mathrm{mmol})$, tosylaziridine $2(2.0 \mathrm{mmol})$, and a catalytic amount of $\mathrm{I}_{2}(0.2$ $\mathrm{mmol})$ in $[\mathrm{bmim}] \mathrm{OH}(5 \mathrm{~mL})$ was stirred at r.t. for 5-6 h. After completion of the reaction as indicated by TLC, $\mathrm{H}_{2} \mathrm{O}$ $(10 \mathrm{~mL})$ was added, and the mixture was extracted thrice 
with EtOAc $(10 \mathrm{~mL})$. The combined organic layer was washed with brine $(10 \mathrm{~mL})$, dried over anhyd $\mathrm{Na}_{2} \mathrm{SO}_{4}$, filtered, and evaporated under reduced pressure to afford an analytically pure sample of a single diastereomers 3 (Table 2). After isolation of the products, the remaining aqueous layer containing the ionic liquid was washed with hexane and dried in vacuum resulting in recycled ionic liquid, [bmim $] \mathrm{OH}$ (Table 3 ). The structure of the product 3 was confirmed by their elemental and spectral analyses.

Characterization Data of Representative Compounds 3 Compound 3a: colorless solid, mp $103-104{ }^{\circ} \mathrm{C}$. IR (KBr): $v_{\max }=3348,3031,2938,1746,1701,1605,1583,1451 \mathrm{~cm}^{-}$ ${ }^{1} .^{1} \mathrm{H}$ NMR $(400 \mathrm{MHz}, 3): \mathrm{d}=2.31(\mathrm{~s}, 3 \mathrm{H}), 2.81$ (ddd, $J=$ $10.8,7.1,4.3 \mathrm{~Hz}, 1 \mathrm{H}$ ), 2.90 (ddd, $J=10.8,8.9,6.5 \mathrm{~Hz}, 1 \mathrm{H}$ ), 4.61 (ddd, $J=8.9,7.5,4.3 \mathrm{~Hz}, 1 \mathrm{H}), 4.89$ (dd, $J=7.1,6.5$ $\mathrm{Hz}, 1 \mathrm{H}), 7.21-7.49(\mathrm{~m}, 10 \mathrm{H}), 7.85-7.98(\mathrm{~m}, 4 \mathrm{H}), 8.12$ (br, exch, $1 \mathrm{H}) .{ }^{13} \mathrm{CNMR}\left(100 \mathrm{MHz}_{3}\right): \mathrm{d}=25.1,33.7,43.3,53.5$, $127.1,127.9,128.6,129.3,130.0,130.7,132.5,133.2$, 133.8, 134.7, 139.2, 140.1, 171.0, 178.3. MS (EI): $\mathrm{m} / z=434$ $\left[\mathrm{M}^{+}\right]$. Anal. Calcd for $\mathrm{C}_{24} \mathrm{H}_{22} \mathrm{~N}_{2} \mathrm{O}_{4} \mathrm{~S}: \mathrm{C}, 66.34 ; \mathrm{H}, 5.10 ; \mathrm{N}$, 6.45. Found: C, 66.59; H, 5.31; N, 6.27

Compound 3e: colorless solid, $\mathrm{mp} 151-153{ }^{\circ} \mathrm{C}$. IR (KBr): $v_{\max }=3355,3032,2925,1741,1701,1596,1577,1451 \mathrm{~cm}^{-1}$. ${ }^{1} \mathrm{H}$ NMR $\left(400 \mathrm{MHz}, \mathrm{CDCl}_{3}\right)$ : d = 2.28 (s, $\left.3 \mathrm{H}\right), 2.78$ (ddd, $J$ $=10.7,7.4,4.8 \mathrm{~Hz}, 1 \mathrm{H}), 2.90(\mathrm{ddd}, J=10.7,9.0,6.6 \mathrm{~Hz}, 1$ H), 4.63 (ddd, $J=9.0,7.5,4.8 \mathrm{~Hz}, 1 \mathrm{H}), 4.85(\mathrm{dd}, J=7.4,6.6$ $\mathrm{Hz}, 1 \mathrm{H}), 7.26-7.53(\mathrm{~m}, 9 \mathrm{H}), 7.88-7.91(\mathrm{~m}, 4 \mathrm{H}), 8.15$ (br, exch, $1 \mathrm{H}) .{ }^{13} \mathrm{C} \mathrm{NMR}\left(100 \mathrm{MHz}, \mathrm{CDCl}_{3}\right): \mathrm{d}=25.5,33.2$, 43.8, 54.0, 127.2, 127.9, 128.7, 129.5, 130.1, 130.8, 131.4, 132.0, 132.7, 133.3, 134.0, 138.9, 171.2, 178.2. MS (EI): $\mathrm{m} / \mathrm{z}$ $=468,470\left[\mathrm{M}^{+}, \mathrm{M}^{+}+2\right]$. Anal. Calcd for $\mathrm{C}_{24} \mathrm{H}_{21} \mathrm{ClN}_{2} \mathrm{O}_{4} \mathrm{~S}: \mathrm{C}$, 61.47; H, 4.51; N, 5.97. Found: C, 61.69; H, 4.13; N, 6.19. Compound 3i: colorless solid, mp $135-137{ }^{\circ} \mathrm{C}$. IR (KBr): $v_{\max }=3350,3029,2932,1743,1702,1601,1578,1445 \mathrm{~cm}^{-1}$. ${ }^{1} \mathrm{H}$ NMR $\left(400 \mathrm{MHz}, \mathrm{CDCl}_{3}\right): \mathrm{d}=2.28(\mathrm{~s}, 3 \mathrm{H}), 2.82(\mathrm{ddd}, J$ $=10.9,7.1,4.3 \mathrm{~Hz}, 1 \mathrm{H}), 2.92(\mathrm{ddd}, J=10.9,8.9,6.7 \mathrm{~Hz}, 1$
H), $4.66(\mathrm{ddd}, J=8.9,7.5,4.3 \mathrm{~Hz}, 1 \mathrm{H}), 4.86(\mathrm{dd}, J=7.1,6.7$ $\mathrm{Hz}, 1 \mathrm{H}), 7.19-7.55$ (m, 9 H), 7.79-7.92 (m, $4 \mathrm{H}), 8.17$ (br, exch, $1 \mathrm{H}) .{ }^{13} \mathrm{C}$ NMR $\left(100 \mathrm{MHz}, \mathrm{CDCl}_{3}\right): \mathrm{d}=25.6,33.1$, $43.5,53.5,127.7,128.4,129.0,129.6,130.3,131.1,131.8$, 132.5, 133.2, 134.0, 134.8, 140.1, 171.0, 178.8. MS (EI): $\mathrm{m} / \mathrm{z}$ $=452\left[\mathrm{M}^{+}\right]$. Anal. Calcd for $\mathrm{C}_{24} \mathrm{H}_{21} \mathrm{FN}_{2} \mathrm{O}_{4} \mathrm{~S}: \mathrm{C}, 63.70 ; \mathrm{H}$, 4.68; N, 6.19. Found: C, 63.89; H, 4.91; N, 5.87.

(34) Brace, N. O. J. Fluorine Chem. 2003, 123, 237.

(35) Isolation of $\mathbf{4 a}(\mathrm{Ar}=\mathrm{Ph}), \mathbf{4 e}\left(\mathrm{Ar}=4-\mathrm{ClC}_{6} \mathrm{H}_{4}\right)$, and $\mathbf{4 i}(\mathrm{Ar}=$ 4- $\left.\mathrm{FC}_{6} \mathrm{H}_{4}\right)$ and Their Conversion into the Corresponding Pyrrolidin-2-ones 3a, 3e, and $\mathbf{3 i}$

The procedure followed was the same as described above for the synthesis of 3 , except that the reaction time in this case was only $2 \mathrm{~h}$ instead of 5-6h used for 3 . To obtain analytically pure samples of $\mathbf{3 a}, \mathbf{3 e}$, and $\mathbf{3 i}$ and to assign stereochemistry the same procedure was adopted as described for 3a, 3e, and 3i. Finally, these intermediates were stirred at r.t. for the next $3-4 \mathrm{~h}$ to give the corresponding cyclized products $\mathbf{3 a}, \mathbf{3 e}$, and $\mathbf{3 i}$ respectively. Characterization Data of Representative Compound Compound 4a: IR (KBr): $v_{\max }=3345,3030,2930,1708$, $1605,1581,1455 \mathrm{~cm}^{-1} .{ }^{1} \mathrm{H}$ NMR $\left(400 \mathrm{MHz},{ }_{3}\right): \mathrm{d}=2.23(\mathrm{~s}$, $3 \mathrm{H}), 2.51-2.53(\mathrm{~m}, 2 \mathrm{H}), 3.81(\mathrm{~m}, 1 \mathrm{H}), 4.01$ (dd, $J=7.9$, $3.8 \mathrm{~Hz}, 1 \mathrm{H}), 5.29$ (br, exch, $1 \mathrm{H}), 7.21-7.59(\mathrm{~m}, 12 \mathrm{H}), 7.85-$ $7.81(\mathrm{~m}, 2 \mathrm{H}) .{ }^{13} \mathrm{C} \mathrm{NMR}\left(100 \mathrm{MHz},{ }_{3}\right): \mathrm{d}=25.1,37.2,45.5$, $64.2,126.7,127.5,128.2,129.0,129.7,130.3,132.0,132.6$, 133.3, 134.0, 135.2, 138.5, 169.8, 177.2. MS (EI): $m / z=434$ [M $\mathrm{M}^{+}$. Anal. Calcd for $\mathrm{C}_{24} \mathrm{H}_{22} \mathrm{~N}_{2} \mathrm{O}_{4} \mathrm{~S}$ : C, 66.34; H, 5.10; N, 6.45. Found: C, 66.63; H, 4.88; N, 6.19.

(36) (a) Wang, Z.; Cui, Y.-T.; Xu, Z.-B.; Qu, J. J. Org. Chem. 2008, 73, 2270. (b) Minakata, S.; Hotta, T.; Oderaotoshi, Y.; Komatsu, M. J. Org. Chem. 2006, 71, 7471. (c) Lu, P. Tetrahedron 2010, 66, 2549. (d) Garima, V. P. S.; Yadav, L. D. S. Green Chem. 2010, 12, 1460. (e) Minakata, S.; Kano, D.; Oderaotoshi, Y.; Komatsu, M. Angew. Chem. Int. Ed. 2004, 43, 79. 